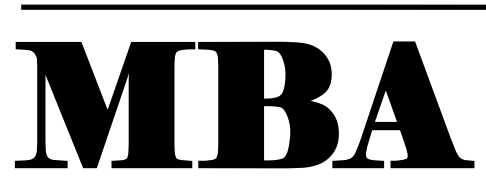

Vol. 5 , No. 1, January 2022, page 505 - 512

ISSN 2614-1981 (Print)

ISSN 2615-0352 (Online)

Journal of Management and Business Aplication

\title{
THE EFFECT OF PERFORMANCE APPRAISAL, COMPENSATION, AND JOB SATISFACTION TO EMPLOYEE ENGAGEMENT AT STIKES DR. SOEBANDI JEMBER
}

\author{
Ariefa Quinta Hanum ${ }^{1}$, Supardi ${ }^{2}$, Yuniorita Indah Handayani ${ }^{3}$ \\ Higher Education of Economic Mandala, JL. Sumatera No 118-120 Jember 68121, Indonesia ${ }^{1,2,3}$
}

Received : 2021/11/17 Corresponding author:

Revised : 2021/11/27 Name: Supardi

Accepted : 2021/12/15 E-mail: supardiav2@gmail.com

\begin{abstract}
The purpose of this study was to analyze the effect of Performance Appraisal, Compensation, and Job Satisfaction either partially or simultaneously on Employee Engagement on STIKES dr. Soebandi. This type of research is quantitative research, with the type of data used is primary data. The sampling technique used the census technique, with a total sample of 86 respondents. The data analysis method used multiple linear regression analysis. The results of the analysis show that partial job appraisal has no significant effect on employee engagement because it produces a significance level above 0.05 . Then, the partial compensation has a significant effect on employee engagement because it produces a significance level below 0.05. Then, the partial job satisfaction has a significant effect on employee engagement because it produces a significance level below 0.05 .
\end{abstract}

Keywords: Performance Assessment, Compensation, Job Satisfaction,

\section{INTRODUCTION}

Human Resources (HR) plays a central role in bringing the company to the peak of glory. he company is very dependent on the talent of its human resources. While we know that the Brain Drain Phenomenon is currently happening a lot, hijacking other companies' HR talents is a common thing and is often done. So competition between companies is not only competing for potential customers, but also for the best human resources/talents across companies.

Then how can the human resources in a company survive and give their best performance? This is where it is important for a company to have a good Employee Engagement strategy. Employee Engagement is a positive attitude or behavior of an employee towards his work and 
organization, which is marked by a feeling of enthusiasm at work and having a high dedication to the work that is his responsibility.

The company will have employees who have good Employee Engagement, if supported by good HR management practices. HR management practices can be carried out through Performance Appraisal, Compensation and Job Satisfaction. This means that if the implementation of HR management is good, it will encourage HR to have good Employee Engagement as well. Based on this, it can be concluded that HR management practices (Performance Appraisal, Compensation and Job Satisfaction) can affect Employee Engagement in achieving organizational/company goals.

Problems related to HR management practices and Employee Engagement are also a concern of STIKES dr. Soebandi. As a company engaged in Health Education, STIKES dr. Soebandi also thought of ways to keep the human resources owned and able to provide good job performance for the company. So far, HR management has been carried out by the company, but this must continue to be developed through an approach to employees, to dig up information about the wishes and expectations of the employees, so that both parties, both employees and the company, do not feel disadvantaged.

\section{The purpose of this research is:}

a. To analyze the effect of partial performance appraisal on Employee Engagement on STIKES dr. Soebandi.

b. To analyze the effect of compensation partially on Employee Engagement on STIKES dr. Soebandi.

c. To analyze the effect of Job Satisfaction partially on Employee Engagement on STIKES dr. Soebandi.

d. To analyze the effect of simultaneous performance appraisal, compensation and job satisfaction on employee engagement at STIKES dr. Soebandi.

\section{Literature review}

Handoko said (1997:135) Performance appraisal is the process by which an organization evaluates or assesses employee performance. This activity can improve personnel decisions and provide feedback to employees on their work performance.

Hasibuan said (2011:118), Compensation is costs for the company. The company expects that the compensation provided will get a higher work performance reward from the employees. So, the value of employee performance must be greater than the compensation paid by the company, so that the company gets a profit and the continuity of the company is guaranteed.

Hasibuan said (2003:88), Job Satisfaction is a pleasant emotional attitude and makes a person feel enjoy and love his job. When employees can feel that the work they are doing makes them happy, then employees will be satisfied and will always carry out their work as well as possible. This attitude is reflected by work morale, work performance and discipline.

Kahn said (1990:694) Employee Engagement is Personal Engagement who utilize themselves as members of the organization to perform their job roles; In this engagement, the employed person expresses himself physically, cognitively, and emotionally during his performance. Robbins and Judge said (2011:113) Employee Engagement is individual engagement with satisfaction and enthusiasm for the work he or she does. 


\section{Research Hypothesis:}

First hypothesis (H1): It is suspected that the Performance appraisal has a partial effect on Employee Engagement on employees at STIKES dr. Soebandi.

Second hypothesis (H2): It is suspected that compensation has a partial effect on Employee Engagement for employees at STIKES dr. Soebandi.

Third hypothesis (H3): It is suspected Job Satisfaction has a partial effect on Employee Engagement on employees at STIKES dr. Soebandi.

Fourth hypothesis (H4): It is suspected Performance appraisal, Compensation and Job Satisfaction simultaneously affect Employee Engagement on employees at STIKES dr. Soebandi.

\section{RESEARCH METHODS}

This research was conducted at STIKES dr. Soebandi Jember, with the research population, all employees of STIKES dr. Soebandi who opened 86 people. The sampling technique used is a census technique where the entire population is used as a research sample. So that the sample used in this study amounted to 86 respondents. This type of research is quantitative research. The data collection method used in this study was through questionnaires, interviews, observation and documentation. So that the type of data used is primary data.

\section{Data Analysis Method}

The data analysis method in this study went through 4 stages, namely:

a. Test Instrument Data

Sugiyono said (2018:15) In a quantitative study, the main criteria for research results are valid, reliable and objective. And to obtain valid and reliable data, the validity and reliability of the research instrument being tested are the research instruments.

b. Classic assumption tesT

The assumption test is used to determine whether the research model has met the classical assumptions, which means that the model used is correct and produces accurate values. The classical assumption test consists of three types, namely the Normality Test, Multicollinearity Test, and Heteroscedasticity Test

c. Multiple Linear Regression Analysis

This analysis is used to determine the regression equation so that it can be seen the direction of the relationship between the independent variables (X1, X2, and $\mathrm{X} 3$ ) on the dependent variable $(\mathrm{Y})$. The multiple linear regression equation in this study is as follows:

$$
\mathrm{Y}=\mathrm{a}+\mathrm{bX} \mathrm{X}_{1}+\mathrm{bX} \mathrm{X}_{2}+\mathrm{b} \mathrm{X}_{3}+\mathrm{e}
$$

Information:

Y : dependent variable

a : constant

b : regression coefficient

$\mathrm{X} 1$ : performance appraisal variable

$\mathrm{X} 2$ : compensation variable

X3 : job satisfaction variable 


\section{d. Coefficient of Determination (R2)}

The coefficient of determination is used to determine how much the independent variable (X) contributes to the dependent variable (Y). The value of R2 is said to be good if it ranges from 0 to 1 .

e. Hypothesis test

Testing this hypothesis is used to determine the effect of the independent variable consisting of Performance Appraisal (X1), Compensation (X2), and Job Satisfaction (X3) on the dependent variable, namely Employee Engagement (Y) both partially (t test) and simultaneous test ( $\mathrm{F}$ test).

\section{RESULT ANALYSIS}

Respondents as many as 86 people in this study consisted of employees from several work units at STIKES dr. Soebandi, including from the Midwifery unit as many as 15 people, from the Nursing unit as many as 30 people, from the Pharmacy unit as many as 10 people, from other units as many as 31 people. To make it easier, it can be seen in the following table

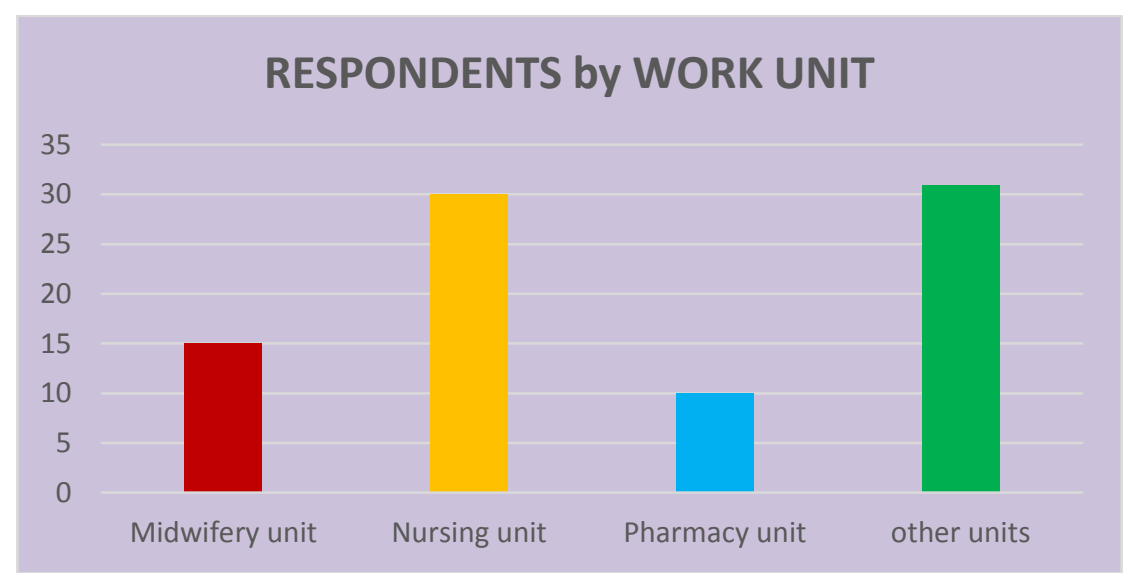

Figure 1. Respondents by Work Unit

\section{Test Instrument Data}

a. Validity test

Based on the validity test, it was found that all research instruments had a calculated $r$ value greater than 0.3 (>0.3), so all instruments were declared valid.

b. Reliability Test

Based on the reliability test that has been carried out, the results show that all instruments have a Cronbach Alpha value $>0.60$, so all instruments are declared reliable.

\section{Classic assumption test}

a. Normality test

Based on the normality test, the results show that the data spreads around the diagonal line and follows the direction of the diagonal line or histogram graph, so that it shows a normal distribution pattern, then the regression model meets the assumption of normality.

b. Multicollinearity Test

Based on the multicollinearity test, the results showed that the Performance Assessment variable had a tolerance value of 0.279 with a VIF value of 3.580 . Then, Compensation 
variable with a tolerance of 0.445 and a VIF value of 2.250. then The Job Satisfaction variable has a tolerance value of 0.311 with a VIF value of 3.210. Thus, because all independent variables have a Tolerance value $>0.10$ and VIF $<10$, it can be stated that there is no multicollinearity.

c. Heteroscedasticity Test

Based on the Heteroscedasticity test conducted, the results show that $\mathrm{P}$ value is more than 0.05 (not significant), meaning that the regression model in this study does not occur heteroscedasticity or passes the heteroscedasticity test.

\section{Multiple Linear Regression Analysis}

Based on the results of multiple linear analysis shows the results that can be explained through the following table:

Table 1 Result of Multiple Linear Regression Analysis

\begin{tabular}{|c|c|c|c|c|c|c|}
\hline & Model & $\begin{array}{r}\text { Unstal } \\
\text { Coef }\end{array}$ & $\begin{array}{l}\text { dized } \\
\text { nts }\end{array}$ & $\begin{array}{l}\text { Standardized } \\
\text { Coefficients }\end{array}$ & $\mathrm{t}$ & Sig. \\
\hline & & B & $\begin{array}{c}\text { Std. } \\
\text { Error }\end{array}$ & Beta & & \\
\hline & (Constan) & 17,769 & 2,734 & & 6,499 & ,000 \\
\hline 1 & X1 & ,118 &, 135 & , 142 &, 875 & ,384 \\
\hline & $\mathrm{X} 2$ & , 105 & ,077 & , 177 & 1,370 &, 175 \\
\hline & X3 & ,294 & ,124 & ,365 & 2,369 & ,020 \\
\hline
\end{tabular}

Source: Attachment of SPSS data processing results

Based on the results of the above analysis, the following regression equation is obtained:

$$
\mathrm{Y}=17,769+0,118 \mathrm{X} 1+0,105 \mathrm{X} 2+0,294 \mathrm{X} 3
$$

By looking at these equations, it can be interpreted that:

a. The constant value is 17.769, meaning that if the Performance Assessment, Compensation and Job Satisfaction are zero, then Employee Engagement is a constant.

b. The regression coefficient of the Performance Appraisal variable (X1) is positive at 0.118, meaning that the relationship between Performance Appraisal and Employee Engagement is directly proportional. If the Performance Appraisal increases by one unit, then Employee Engagement will also increase by $11.8 \%$.

c. The regression coefficient of the Compensation variable (X2) is positive at 0.105, meaning that the relationship between Compensation and Employee Engagement is directly proportional. If Compensation increases by one unit, Employee Engagement will also increase by $10.5 \%$.

d. The regression coefficient of the Job Satisfaction variable (X3) has a positive value of 0.294, meaning that the relationship between Job Satisfaction and Employee Engagement is directly proportional. If Job Satisfaction increases by one unit, then Employee Engagement will also increase by $29.4 \%$. 


\section{Coefficient Of Determination (R2)}

Tabel 2 Result of Coefficient Of Determination

\begin{tabular}{|c|c|c|c|c|c|}
\hline Model & $\mathrm{R}$ & $\begin{array}{l}\text { R } \\
\text { Square }\end{array}$ & $\begin{array}{l}\text { Adjusted } \\
\text { Square }\end{array}$ & $\mathrm{R}$ & $\begin{array}{l}\text { Std. Error } \\
\text { of the } \\
\text { Estimate }\end{array}$ \\
\hline 1 & $628^{\mathrm{a}}$ & ,395 &, 372 & & 3,580 \\
\hline
\end{tabular}

Source: Attachment of SPSS data processing results

Based on the table above, the results obtained by adjusting $\mathrm{R}$ square are 0.372 . This means that the contribution of the variables of Performance Appraisal, Compensation and Job Satisfaction in providing the information needed to predict variations in Employee Engagement is $37.2 \%$, thus the rest of the other variables not used in this study.

\section{Hypothesis testing}

\section{Partial Test (t test)}

Table 3. Coefficients

\begin{tabular}{|c|c|c|c|c|c|c|c|c|}
\hline \multirow{2}{*}{\multicolumn{2}{|c|}{ Model }} & \multicolumn{2}{|c|}{$\begin{array}{l}\text { Unstandardized } \\
\text { Coefficients }\end{array}$} & \multirow{2}{*}{$\begin{array}{l}\text { Standardized } \\
\text { Coefficients } \\
\text { Beta }\end{array}$} & \multirow[t]{2}{*}{$\mathrm{t}$} & \multirow[t]{2}{*}{ Sig. } & \multicolumn{2}{|c|}{$\begin{array}{c}\text { Collinearity } \\
\text { Statistics }\end{array}$} \\
\hline & & $\mathrm{B}$ & $\begin{array}{l}\text { Std. } \\
\text { Error }\end{array}$ & & & & Tolerance & VIF \\
\hline & (Constant) & $\begin{array}{l}17,76 \\
9\end{array}$ & 2,734 & & 6,499 & , 000 & & \\
\hline \multirow[t]{3}{*}{1} & $\mathrm{X} 1$ & ,118 & , 135 & , 142 & 875 & 384 & ,279 & 3,580 \\
\hline & $\mathrm{X} 2$ & , 105 & ,077 & , 177 & 1,370 & ,015 & ,445 & 2,250 \\
\hline & X3 & 294 & , 124 & ,365 & 2,369 & ,020 & ,311 & 3,210 \\
\hline
\end{tabular}

Source: Attachment of SPSS data processing results

Based on the table above shows that the partial effect of each independent variable on the dependent variable is as follows:

a. The Performance Appraisal variable has a significance level of 0.384 . This means that the significance value is greater than the predetermined significance value of $0.05(0.384>0.05)$, so that it can be concluded that the Performance Appraisal variable partially has no significant effect on Employee Engagement.

b. Compensation variable has a significance level of 0.015 . This means that the significance value is smaller than the predetermined significance value of $0.05(0.015<0.05)$, so it can be concluded that the compensation variable partially has a significant effect on Employee Engagement.

c. Job Satisfaction variable has a significance level of 0.020 . This means that the significance value is smaller than the predetermined significance value of $0.05(0.020<0.05)$, so it can be concluded that the variable job satisfaction partially has a significant effect on Employee Engagement. 
Table 4 Simultaneous Test (F test)

\begin{tabular}{|c|c|c|c|c|c|c|}
\hline \multicolumn{2}{|c|}{ Model } & Sum of & df & Mean & $\mathrm{F}$ & Sig. \\
\hline \multirow{3}{*}{1} & Regression & 685.069 & 3 & 228.356 & 17.815 & $000^{\mathrm{b}}$ \\
\hline & Residual & 1051,070 & 82 & 12,818 & & \\
\hline & Total & 1736,140 & 85 & & & \\
\hline
\end{tabular}

Source: Attachment of SPSS data processing results

Based on the table above shows that the significance value is 0.000 , meaning that the value is smaller than the predetermined significance value of $0.05(0.000<0.05)$, so it can be concluded that the independent variables consisting of Performance Appraisal (X1), Compensation (X2), Job Satisfaction (X3) simultaneously affect the dependent variable Employee Engagement (Y). Thus the hypothesis can be accepted.

\section{INTERPRETATION}

Based on all the results of the analysis that has been carried out, it can be interpreted as follows:

\section{The Effect of Performance Appraisal on Employee Engagement}

The results of the analysis carried out show that Performance Appraisal has no significant effect on Employee Engagement. This happened because at STIKES dr. Soebandi, the current performance appraisal aspect is not in accordance with the organization's vision and mission. The current performance appraisal aspect is also not related to the company's long-term plan. In fact, aspects of the Performance Appraisal have not yet met the cycle stages review planning, coaching and councelling. The current Performance Appraisal has not evaluated all aspects of employee performance, has not gone through an open discussion between superiors and subordinates about what is to be achieved, and has not provided positive and negative feedback that can be used for employee development itself.

The existing performance appraisal system also has not assessed what should be assessed, because the assessment has not been based on the things that are the job desk and the responsibilities of each employee. In other words, the existing performance appraisal system has not fulfilled the sense of justice for employees

\section{Effect of Compensation on Employee Engagement}

Based on the analysis conducted, it shows that the compensation variable in STIKES dr. Soebandi has a significant effect on Employee Engagement, This is because the company is considered sufficient to give appreciation to its employees. When viewed from the answers to the questionnaire submitted by researchers to employees, it shows that employees are satisfied with policies related to compensation for employees including work facilities, salaries, creation programs, and monthly salary receipts. Promotions and rewards given by STIKES dr. Soebandi to employees is considered very good. In addition, STIKES dr. Soebandi also always checks the employee development implementation plan periodically as needed, for example preparing a plan to carry out training, education and training, and so on.

\section{The Effect of Job Satisfaction on Employee Engagement}

Based on the results of the analysis, it shows that job satisfaction has a significant effect on employee engagement. Salaries received by employees are in accordance with the standard of 
living and expectations of employees STIKES dr. Soebandi. The existing facilities and infrastructure in the workplace are sufficient to support the performance of employees in each work unit. Leaders always provide support to subordinates at STIKES dr. Soebandi in employee development, for example by giving the task of participating in training to increase skills. In addition, the leadership is also always fair to its employees, so that employees feel comfortable in carrying out their duties and responsibilities. The rules regarding promotions set by the company are also in accordance with the expectations and desires of the employees of STIKES dr. Soebandi.

\section{CONCLUSION}

From the analysis that has been done, it can be concluded that partial job appraisal has no significant effect on employee engagement because it produces a significance level above 0.05. Then, the partial compensation has a significant effect on employee engagement because it produces a significance level below 0.05 . Then, the partial job satisfaction has a significant effect on employee engagement because it produces a significance level below 0.05 .

\section{REFERENCES}

Anke Priyono, F. M. (2012). Pengaruh Gaya Kepemimpinan Terhadap Kepuasan Kerja Dan Komitmen Manajemen Pada Laboratorium Mawar. Journal of Business and Banking, 2(1), 113. https://doi.org/10.14414/jbb.v2i1.436

Danendra, AA Ngurah Bagus and Ni Wayan Mujiati 02016) The Influence of Motivation, Compensation and Organizational Commitment on Organizational Citizenship Behavior (OCB), E- Journal of Management of Udayana University, Vol5, No.10, 2016: 6229-6259, ISSN: 2302-8912.

Ferdinand, A. (n.d.). Metode Penelitian Manajemen [Out of Print].

Handoko, T Hani. 1997. Manajemen Personalia dan Sumber Daya Manusia. Yogyakarta: UGM

Hasibuan, M. 2003. Organisasi dan Motivasi Dasar Peningkatan Produktivitas. Jakarta: Bumi Aksara

Hasibuan, Malayu S.P, 2011. Manajemen Sumber Daya Manusia. Jakarta: PT Bumi Askara

Hasibuan, Malayu SP2007. Human Resource Management Company, Bandung, PT. Earth Aksa.

Kahn, W.A. 1990. Psychological Conditions Of Personal Engagement And Disengagement at Work. Academy of Management Journal. Vol 33, pp 692- 724.

Martha, Y., \& Simanungkalit, V. (2013). Pengaruh Gaya Kepemimpinan Terhadap Kepuasaan Kerja Karyawan pada PT. LMA. UG Jurnal, Vol. 7(No. 06), 30-33.

Pratikto Bagus Tri, I ketut R Sudiartha, Sholikhah, The Influence of Job Satisfaction and Leadership Style on Organizational Citizhenship Behavior (Study at PT Ide Jaya Kreasindo), Indonesian Science Management Research Journal (JRMSI), Vol 6, No.2.2015 Hl 498- 515

Richard L. Daft. (2003). Management 8thed. Southwestern: Thomson

Robbins, Stephen P. \& A. Judge, Timothy. 2011. Organizational behavior. Fourteenth Edition. Pearson education. New Jersey 07458. 77-89

Sugiyono, P. D. (2014). Populasi dan sampel. Metode Penelitian Kuantitatif, Kualitatif Dan $R \& D$, (April 1952), 80.

Sugiyono. (2011). Statistika untuk penelitian. Bandung: Alfabeta.

Sugiyono. 2018. Metode Penelitian Kuantitatif. Bandung: Alfabeta 